Alicja Chrabańska-Czerwińska

Uniwersytet Ekonomiczny w Krakowie

alicja.chrabanska@gmail.com

\title{
Wpływ „odmrożenia” gospodarki po blokadzie z powodu COVID-19 na natężenie ruchu turystycznego w Tatrzańskim Parku Narodowym
}

\section{Streszczenie}

W wyniku ogłoszenia światowej pandemii COVID-19 w marcu 2020 r. w Polsce ustanowiono tzw. lockdown. Poza uniemożliwieniem bądź ograniczeniem działalności wielu gałęzi gospodarki, zamknięto również czasowo ruch turystyczny oraz rekreacyjny w parkach i lasach. Wiązało się to $z$ brakiem możliwości legalnego wejścia na teren Tatrzańskiego Parku Narodowego. Celem niniejszego rozdziału jest zbadanie, jak czasowe wyłączenie możliwości uprawiania turystyki w Tatrach wpłynęło na natężenie ruchu turystycznego w okresie „odmrażania gospodarki” i późniejszym w oparciu o analizy liczby sprzedanych biletów, ale również zapisków kroniki interwencji TOPR w okresie od maja do września 2019 r. oraz w analogicznym okresie 2020 r.

\section{Wprowadzenie}

W 2020 r. kluczowym zagadnieniem poruszającym całe społeczeństwa był rozwój pandemii COVID-19. W Polsce od 20 marca 2020 r. wprowadzony został stan epidemii, z którym wiązały się liczne obostrzenia, a w konsekwencji ich narastania zamknięcie gospodarki (GOV, 2020). Jeden z istotnych zakazów dotyczył zamknięcia parków i lasów. Skutkiem tego 13 marca 2020 r. zamknięty został także Tatrzański Park Narodowy. 4 maja 2020 r. TPN ogłosił ponowne otwarcie parku (TPN, 2021). Ponieważ lockdown był wyjątkową sytuacją w dziejach III RP,

Cytowanie: Chrabańska-Czerwińska A. (2021). Wpływ „odmrożenia” gospodarki po blokadzie z powodu COVID-19 na natężenie ruchu turystycznego w Tatrzańskim Parku Narodowym. W: K. Borodako (red.), Turystyka w okresie pandemii. Bogucki Wydawnictwo Naukowe, Poznań-Kraków, s. 241-249. https://doi. org/10.12657/9788379863501-23 
niełatwo było opracować prognozy, jak wpłynie on na poszczególne gałęzie gospodarki. Również niewiadomą było, jak zareaguje turystyka górska ani czy turyści po okresie zamknięcia szlaków tłumnie wznowią ruch turystyczny, kompensując jego brak w okresie od połowy marca do początku maja czy też ciągle obecny stan światowej pandemii, ryzyko zakażeń i strach spowodują zmniejszenie ruchu turystycznego $\mathrm{W}$ stosunku do analogicznego okresu w roku ubiegłym. W niniejszym rozdziale podjęto tematykę wpływu „odmrożenia” gospodarki polskiej po okresie zamknięcia na liczbę turystów w TPN. Podstawowym miernikiem natężenia ruchu turystycznego była liczba sprzedanych biletów wstępu. Analizie poddano także interwencje TOPR w analogicznych okresach 2019 i 2020 r. W związku z ograniczonymi możliwościami podróżowania oraz długim okresem, w którym większość aktywności została ograniczona, uznano za prawdopodobne, że turystykę górską wybrała większa liczba osób o niższych kwalifikacjach.

\section{Turystyka górska - formy}

Punktem wyjścia do rozważań na temat turystyki górskiej musi być stwierdzenie, że wiąże się ona $z$ intencjonalną aktywnością fizyczną, zarówno pod kątem sportowym, jak i hobbystycznym (Merski, Warecka, 2009).

W skład szeroko pojmowanej turystyki aktywnej wchodzi turystyka kwalifikowana, która zgodnie z nazwą wymaga szczególnych kwalifikacji - od kwestii dotyczących formy fizycznej turysty po specjalne uprawnienia, licencje czy też specjalistyczny sprzęt (Kurek i in., 2007). Mokras-Grabowska (2015) wskazuje, że turystyka kwalifikowana $\mathrm{w}$ tym rozumieniu dotyczy nielicznej grupy turystów, którzy do turystyki mają podejście bardzo ambicjonalne i dążą do wysokich i wybitnie wysokich kwalifikacji w tej dziedzinie. Podkreśla nieodzowne cechy turystyki kwalifikowanej, takie jak specyficzne czynniki motywujące turystę (wyczyn turystyczny, zdobywanie szczytów, odznak), kompetencje twarde, np. umiejętności wspinaczkowe, przygotowanie psychofizyczne oraz proaktywna postawa w organizacji.

Można zauważyć, że pojęcie turystyki kwalifikowanej zazębia się z istnieniem obszaru, który nazwać można turystyką sportową. Najprościej ujmując, jest to turystyka kwalifikowana, szczególnie nastawiona na ruch, ekspozycję na ryzyko, osiąganie celów sportowych, której elementem jest kontemplacja przyrody (Ghețe, 2016). Turystykę sportową od uprawiania sportu sensu stricte odróżnia brak rywalizacji między sportowcami, jak również konieczność przemieszczenia poza miejsce stałego zamieszkania (Tomik, 2013).

W kontekście turystyki, szczególnie turystyki sportowej, możemy mówić także o turystyce ekstremalnej. Niewątpliwie wiąże się ona z wyczynami sportowymi, jednak kładzie nacisk na zaistnienie elementu ryzyka. Dotyczyć może uprawiania sportów niszowych, w przypadku Tatr może to być wspinaczka na drogach nieubezpieczonych czy też wspinaczka zimowa po lodospadach. Grono turystów, którzy podejmują taki rodzaj aktywności, jest bardzo zawężone (Malchrowicz-Mośko, Sekida, 2016). Warto jeszcze przywołać pojęcie eko-turystyki jako formy 
nastawionej na przyrodę, naturę, jej ochronę, która zdecydowanie może odnosić się do ruchu turystycznego w Tatrach. W ujęciu szerszym również zaangażowanie w ochronę dorobku kulturowego, odpowiedzialny marketing i zaangażowanie lokalnych społeczności w działania (Sambotin i in., 2011).

\section{Tatrzański Park Narodowy - atrakcje i natężenie ruchu turystycznego w poszczególnych punktach}

Tatrzański Park Narodowy w obecnej formie istnieje od 1 stycznia 1955 r. Od tego czasu powierzchnia łączna parku ulegała zmianom, by ostatecznie w $2018 \mathrm{r}$. osiągnąć 21 197,11 ha. TPN oferuje liczne atrakcje dla zwiedzających w postaci $275 \mathrm{~km}$ ścieżek pieszych i tras narciarskich, 6 ścieżek rowerowych i tyluż jaskiń. Zauważyć można, że z roku na rok rośnie liczba turystów w Tatrach, konkretne jednak wartości liczbowe podano w dalszej części pracy (Szlubowska, 2020). Wejście na teren parku wymaga wniesienia opłaty, określonej w zarządzeniu dyrektora TPN. Istotną informacją w kontekście sprzedaży biletów jest fakt, że $15 \%$ wpływów z opłat przekazywane jest na rzecz działalności ratowniczej TOPR (TPN, 2021). Administracją parku zarządza dyrektor, którym od 1 kwietnia 2014 r. jest Szymon Ziobrowski (BIP, 2016). Bogata oferta Tatrzańskiego Parku Narodowego pozwala na uprawianie turystyki w wielu aspektach. Drogi wspinaczkowe oraz dostępność obszarów górskich dla skiiturowców pozwalają na rozwój turystyki z jednej strony ekstremalnej, a z drugiej sportowej (w zależności od założonych celów). Wyjścia w partie górskie, powyżej schronisk, wymagają dobrej sprawności fizycznej, wpisując się w ideę turystyki kwalifikowanej. Duża dostępność dolin i ścieżek o niskim stopniu trudności pozwala na uprawianie w TPN szeroko pojętej turystyki aktywnej. Działalność noclegowa schronisk może z powodzeniem zostać zakwalifikowana do ekoturystyki.

Do głównych atrakcji Tatrzańskiego Parku Narodowego zdecydowanie należą szlaki piesze. Według statystyk przytaczanych przez Skowrońskiego (2010) około jednej czwartej wszystkich turystów udaje się w kierunku Morskiego Oka. Na drugim miejscu znalazły się szlaki prowadzące z Kuźnic w wyższe partie Tatr (np. Hala Gąsienicowa), następnie była to Dolina Kościeliska oraz kolej linowa na Kasprowy Wierch.

Hibner (2012) w swoich badaniach dotyczących zróżnicowania ruchu turystycznego w Tatrach jako obiekty badań wybrał takie atrakcje, jak Orla Perć, Kasprowy Wierch i Dolina Strążyska. Orla Perć, uznawana za najtrudniejszy szlak w Polsce, ma 3,9 km. Kasprowy Wierch, znajdujący się w Tatrach Zachodnich, swoją ogromną popularność zawdzięcza wybudowanej w 1936 r. kolejce. Dolina Strążyska jest atrakcją Tatr Reglowych, jest stosunkowo łatwo dostępna z centrum Zakopanego, a jej powodzenie wynika z tego, że prowadzi przez nią szlak na Giewont. 


\section{Ratownictwo górskie - Tatrzańskie Ochotnicze Pogotowie Ratunkowe jako organizacja udzielająca pomocy turystom w Tatrach}

Już samo pojęcie turystyki aktywnej górskiej wiąże się z pewnymi elementami zwiększonego ryzyka wypadków bądź drobniejszych urazów. Trudne ukształtowanie terenu, zmienne warunki, jak również brak dostępności tych miejsc dla standardowych służb ratunkowych sprawiają, że turyści, którzy ulegają wypadkom, których dotykają kontuzje lub którzy tracą rozeznanie w terenie, potrzebują pomocy wyspecjalizowanych ratowników. Ze względu na kraj/region położenia danego pasma górskiego, natężenie ruchu turystycznego i charakterystykę pasm górskich kwestie dotyczące ratownictwa górskiego kształtują się w różny sposób. W polskich Tatrach pomoc niosą ratownicy TOPR. Odpowiedzialna i niezwykle ważna jest rola, jaką górskie służby ratunkowe pełnią w rozwoju turystyki. Można założyć, że dzięki nim turyści czują się bezpieczni, skutkiem czego chętniej wyruszają w różne partie Tatr.

Pomoc poszkodowanym w Tatrach po stronie polskiej niosą ratownicy górscy, członkowie Straży Ratunkowej, która stanowi jedną z dwóch jednostek organizacyjnych Tatrzańskiego Ochotniczego Pogotowia Ratunkowego. Drugą jednostką organizacyjną TOPR jest Zarząd i Walne Zgromadzenie Członków. Poza ratowaniem zdrowia i życia turystów na terenach tatrzańskich w zakres celów realizowanych przez TOPR wchodzi działalność edukacyjna, ochrona środowiska, wzmożenie bezpieczeństwa na szlakach turystycznych w Tatrach, ale też szeroko pojęte propagowanie aktywności fizycznej (Statut Tatrzańskiego Ochotniczego Pogotowia Ratunkowego z dnia 28 października 2017 r.). Pod kątem formy prawnej TOPR jest stowarzyszeniem, wpisanym do rejestru organizacji non profit (TOPR, 2021).

W kontekście akcji ratunkowych i innych interwencji TOPR w terenie warto przyjrzeć się Straży Ratunkowej jako suborganizacji wewnątrz struktury TOPR. Już w postanowieniach ogólnych Regulaminu Straży Ratunkowej Tatrzańskiego Ochotniczego Pogotowia Ratunkowego z dnia 21 lutego 2019 r. wskazane są cele organizacji: organizowanie, kierowanie, koordynacja i prowadzenie akcji ratowniczych, ponadto opracowywanie komunikatów lawinowych oraz prowadzenie szkoleń dla ratowników górskich. Aby zapewnić wysoką jakość świadczonych usług, wstąpienie w szeregi Straży Ratunkowej jest obwarowane licznymi wymaganiami. Ważne jest, że jednym z regulaminowych obowiązków ratownika jest ciągłe utrzymywanie wysokiej sprawności fizycznej oraz rozwój kwalifikacji w dziedzinie ratownictwa i działalności górskiej. W regulaminie zapisane są szczegółowo wymagane szkolenia, ale również kwestie dotyczące podnoszenia kwalifikacji w postaci systemu szkolenia ratowników górskich.

Najważniejsze jednak w kontekście niniejszej pracy jest przedstawienie, zgodnie z Regulaminem Straży..., rodzaju działań ratunkowych w Tatrach:

- interwencja - forma krótkotrwała, zakładająca pomoc przedmedyczną bez konieczności transportowania poszkodowanego, 
- akcja ratunkowa - każde działanie, które w konsekwencji wymaga transportu poszkodowanego i przekazania jednostkom PRM,

- fałszywe (zbędne) alarmy - zgłoszenie, które skutkowało podjęciem działania ratunkowego na zorganizowanym obszarze narciarskim, a które okazało się zbędne lub fałszywe.

\section{Analiza porównawcza danych ilościowych dotyczących interwencji TOPR oraz sprzedaży biletów do TPN w okresie od maja do września 2019 i 2020 r.}

Analiza natężenia i struktury ruchu turystycznego jest niezwykle istotna z punktu widzenia decyzji związanych z ochroną przyrody, infrastrukturą turystyczną oraz szeroko pojętego zarządzania turystyką. Badania takie powinny prowadzić do określenia dopuszczalnego obciążenia szlaków i ewentualnego ograniczenia ilości możliwych wejść na teren parku narodowego. W Tatrzańskim Parku Narodowym kluczową formą pomiaru natężenia ruchu turystycznego jest monitorowanie liczby sprzedanych biletów. Periodycznie jednak, w zależności od potrzeb informacyjnych, dodatkowo prowadzone są obserwacje bezpośrednie, polegające na zliczaniu turystów na szlakach w określonych punktach (Buchwał, Fidelus, 2010). Statystyki sprzedanych biletów w poszczególnych punktach prowadzi TPN, udostępniając je na swoim portalu internetowym. Celem rozdziału jest określenie, jak „odmrożenie” gospodarki po okresie zamknięcia wpłynęło na liczbę turystów na szlakach Tatrzańskiego Parku Narodowego. Dokonana została analiza ilościowa sprzedanych biletów, a na jej tle liczby działań ratowniczych TOPR od maja do września 2019 i 2020 r. Warto nadmienić, że podsumowanie dotyczy tylko realnie sprzedanych biletów, nie uwzględnia doszacowania, które publikowane jest przez administrację TPN po zakończeniu roku. W związku z oczywistym brakiem danych za 2020 r., współczynnik doszacowujący został pominięty. Wyniki analizy ilościowej wezwań ratowników zostały porównane z liczbą sprzedanych biletów celem potwierdzenia słuszności korelacji pomiędzy liczbą turystów a liczbą zdarzeń podlegających działaniom TOPR w podziale na interwencje, akcje ratunkowe i fałszywe/zbędne alarmy.

\section{Analiza ilościowa interwencji TOPR w latach 2019 i 2020 oraz wolumeny sprzedanych biletów wstępu do TPN}

Kronika TOPR (www.topr.pl) jest publikowana na stronie internetowej tej organizacji co tydzień i obejmuje wydarzenia z całego tygodnia. Opis każdego działania ratunkowego zawiera detale pozwalające zakwalifikować je do odpowiedniej grupy według klasyfikacji zawartej w Regulaminie Straży Ratunkowej. Dane ilościowe dotyczące sprzedaży biletów podane są za statystykami TPN pobranymi ze strony parku (TPN, 2020). 
Tabela 1. Liczba sprzedanych biletów w TPN w okresie maj-sierpień 2019 oraz 2020 r.

\begin{tabular}{lcc}
\hline \multicolumn{1}{c}{ Miesiąc } & 2019 & 2020 \\
\hline Maj & 270439 & 113842 \\
Czerwiec & 407979 & 285598 \\
Lipiec & 732199 & 703361 \\
Sierpień & 882046 & 791484 \\
\hline
\end{tabular}

Źródło: opracowanie własne na podstawie danych TPN (2020).

Pomimo zamknięcia granic TPN do 4 maja 2020 r. kronika TOPR donosiła o łamaniu zakazu i wynikających z tego interwencjach (łącznie opisane są 2 interwencje w marcu i $1 \mathrm{w}$ kwietniu). Właściwy jednak okres do dalszych rozważań nastąpił od 4 maja. W pierwszym tygodniu funkcjonowania parku TOPR podjął 3 interwencje (w rozumieniu regulaminu). W kolejnym tygodniu wzywany był do poszkodowanych aż sześciokrotnie, wszystkie zdarzenia zaliczamy do interwencji. W następnych tygodniach ratownicy podjęli 10 akcji ratunkowych, odnotowano 2 ofiary śmiertelne, 4 interwencje (w tym 2 wezwania skutkujące podaniem jedynie wytycznych turystom). Według statystyk sprzedaży biletów liczba turystów wyniosła 113 842, przy 20 interwencjach TOPR. W analogicznym okresie 2019 r. TOPR podjął działania 42 razy (29 akcji, 13 interwencji, 1 ofiara śmiertelna), dwukrotnie wezwanie można uznać za zbędne. Łączna liczba biletów była z kolei ponad 2 razy wyższa niż w roku kolejnym i wynosiła 270439 . Istotne jest zauważenie faktu, że w obu przypadkach odsetek wypadków i stosunku do ilości turystów był podobny i wynosił kolejno $0,017 \%$ oraz $0,016 \%$.

W czerwcu turystyka mogła ruszyć pełną parą, co przełożyło się na liczbę wezwań TOPR oraz łączną sprzedaż biletów. W 2020 r. ratownicy podjęli akcje ratunkowe 27 razy, łącznie wszystkich przypadków było 39. Uwzględnić należy także 5 bezpodstawnych lub niewymagających interwencji wezwań. Sprzedaż biletów wyniosła 285 598. W analogicznym okresie 2019 r. Straż Ratunkowa działała w terenie 40 razy, 3 razy wezwania były bezzasadne. Liczba sprzedanych biletów była bardzo duża i wynosiła 407979 . Przeliczenie procentowe wskazuje 0,016\% wypadków na liczbę turystów w 2020 r. oraz 0,011\% dla 2019 r. Widać zatem, że im większa liczba turystów, tym współczynnik ten ma większą tendencję do wypłaszczania się do 0,011\%, im mniejsze liczby, tym bardziej oscyluje wokół 0,016\%.

Lipiec 2020 r. był okresem rozkwitu turystyki górskiej. TPN odwiedziło 703361 osób, co stanowi ponad dwukrotność liczby sprzedanych biletów w czerwcu. Również ponaddwukrotnie wzrosła liczba zgłoszeń do centrali TOPR. Ratownicy podjęli akcję 52 razy (w tym 1 wypadek śmiertelny) oraz interweniowali 21 razy. W 5 przypadkach działanie ze strony TOPR po podjęciu informacji było niewymagane. W 2019 r. liczba turystów była porównywalna (732 199 osób). Również porównywalna była liczba zgłoszeń zdarzeń na szlakach. TOPR koordynował akcję 51 razy (2 ofiary śmiertelne), podjął też 34 interwencje, przy czym ani razu zgłoszenie nie mogło zostać uznane za niekonieczne. W obu przypadkach odsetek interwencji w stosunku do liczby turystów wynosił 0,011\%. 
Tabela 2. Liczba wezwań TOPR w okresie maj-sierpień 2019 oraz 2020 r.

\begin{tabular}{llcc}
\hline \multicolumn{1}{c}{ Miesiąc } & Rodzaj wezwania & 2019 & 2020 \\
\hline Maj & Interwencje & 13 & 10 \\
& Akcje & 29 & 10 \\
& Fałszywe alarmy & 0 & 0 \\
\hline Czerwiec & Interwencje & 11 & 12 \\
& Akcje & 40 & 27 \\
& Fałszywe alarmy & 3 & 5 \\
\hline Lipiec & Interwencje & 34 & 21 \\
& Akcje & 51 & 52 \\
& Fałszywe alarmy & 0 & 5 \\
\hline Sierpień & Interwencje & $14^{*}$ & 45 \\
& Akcje & $31^{*}$ & 61 \\
& Fałszywe alarmy & 0 & 0 \\
\hline
\end{tabular}

Źródło: opracowanie własne na podstawie danych TPN (2020).

*dane za połowę miesiąca

W sierpniu 2020 r. liczba sprzedanych biletów wzrosła jeszcze w stosunku do lipca i wyniosła 791 484. Rekordowo duża była liczba interwencji TOPR i wyniosła 106 (61 akcji i 45 interwencji). W tym samym miesiącu roku poprzedniego liczba sprzedanych biletów była rekordowa i uplasowała się na poziomie 882 046. Analiza ilościowa działań TOPR w sierpniu 2019 r. jest znacznie utrudniona, ponieważ brakuje w niej danych za około 2 tygodnie sierpnia. Dla potrzeb wyliczeń załóżmy jednak, że liczbę sprzedanych biletów należy podzielić przez 2 (441 023). Zatem w ciągu dwóch tygodni (pierwszy i ostatni tydzień sierpnia) TOPR interweniował łącznie 41 razy (31 akcji i 14 interwencji). Wyliczenia procentowe znów wskazują na pewną stałą tendencję i dla 2020 r. wynoszą 0,013\%, $z$ kolei dla połowy miesiąca $0,010 \%$, przy czym należy zaznaczyć, że analiza sierpnia 2019 r. jest robocza i trudno określić jej wiarygodność bez pełnych danych. Założyć można jednak, że po raz kolejny przy pełnych danych procent ten oscylowałby wokół 0,011\%.

\section{Wnioski z analiz}

Zestawienie liczby sprzedanych biletów wstępu do TPN wskazuje, że „odmrożenie" gospodarki po zamknięciu nie wywołało zwiększenia ruchu turystycznego w okresie bezpośrednio następującym po złagodzeniu obostrzeń. Zwłaszcza maj był miesiącem wyjątkowo słabym turystycznie w TPN. Należy zaznaczyć, że ruch turystyczny został wznowiony dopiero po majówce, która zwykle charakteryzuje się wysoką aktywnością turystów. Kolejnym powodem zmniejszonej liczby zakupionych biletów może być słaby przepływ informacji i niewiedza dotycząca otwarcia granic parku, ale można też założyć, że ludzi powstrzymywał strach przed pandemią oraz same zachorowania czy kwarantanny. Czerwiec podobnie 
pokazał, że stan pandemii ciągle trwa, co przekłada się na dużo słabszy ruch turystyczny w TPN niż w roku ubiegłym. Dopiero w lipcu i sierpniu 2020 r. liczba sprzedanych biletów do parku zaczęła zbliżać się do wartości z zeszłego roku, wciąż jednak im nie dorównując. Równoległa analiza ilościowa działań TOPR w poszczególnych miesiącach pokazała, że odsetek zdarzeń wymagających zaangażowania ratowników był względnie stały i skorelowany z liczbą turystów ogółem. Wraz ze wzrostem natężenia ruchu turystycznego wzrastała liczba interwencji TOPR. Należy jednak pamiętać, że wskaźnik wykazuje dużą wrażliwość na czynniki zewnętrzne, np. warunki na szlakach, które mogą prowadzić do wzmożonej liczby wypadków.

\section{Zakończenie}

Aktualnie najbardziej wiarygodnym i miarodajnym wskaźnikiem natężenia ruchu turystycznego jest sprzedaż biletów w punktach wejścia do TPN, skorygowana o współczynnik wejść poza godzinami pracy kas, odwiedzin parku przez okolicznych mieszkańców, dla których wstęp jest darmowy, oraz inne elementy ustalone w statystykach TPN. Liczba działań ratunkowych TOPR rośnie wraz ze wzrostem ruchu turystycznego w TPN, jednak bez analizy jakościowej (warunki pogodowe, podział na profesjonalistów - taterników, grotołazów oraz turystów bez profesjonalnego przygotowania, zagregowanie zdarzeń np. pod względem uszczerbku na zdrowiu, inne szczególne okoliczności) nie stanowi dobrego wskaźnika trendów. Ostatecznie, opierając się na analizie liczby sprzedanych biletów, można stwierdzić, że ruch turystyczny w TPN nie wrócił do swoich rozmiarów sprzed blokady, wykazując pierwszy od kilku lat spadek łącznej liczby turystów odwiedzających park. W toku dalszych rozważań warto byłoby zbadać kluczowe przyczyny spowolnienia turystyki w Tatrach, którymi mogą być strach przed pandemią, przebycie choroby czy też nałożenie kwarantanny.

\section{Literatura}

Buchwał A., Fidelus J. (2010). Monitoring ruchu turystycznego przy użyciu czujników ruchu na przykładzie Tatrzańskiego i Babiogórskiego Parku Narodowego. Zakopane. Nauka a Zarządzanie Obszarem Tatr i ich Otoczeniem, 3: 45-54.

Ghețe A.M. (2016). Classification of Various Forms of Tourism. Annals of Faculty of Economics, University of Oradea, 25, 2: 313-319.

Giergiczny M., Zwijacz-Kozica T. (2018). Optymalny społecznie model ochrony lasów Tatrzańskiego Parku Narodowego dotkniętych zjawiskami klęskowymi. Studia i Materiały CEPL w Rogowie, 54, 4: 69-74.

Hibner J. (2012). Zróżnicowanie ruchu turystycznego w Tatrzańskim Parku Narodowym na wybranych przykładach. Problemy Ekologii Krajobrazu, 34: 41-47.

Kurek W., Mika M., Pitrus E. (2007). Formy turystyki kwalifikowanej. W: W. Kurek (red.), Turystyka. Wydawnictwo Naukowe PWN, Warszawa. 
Malchrowicz-Mośko E., Sekida M. (2016). Turystyka ekstremalna vs. sporty ekstremalne. Journal of Education, Health and Sport, 6: 12.

Merski J., Warecka J. (2009). Turystyka kwalifikowana. Turystyka aktywna. DrukTur, Warszawa.

Mokras-Grabowska J. (2015). Turystyka kwalifikowana - od idei do praktyki. Przykład turystów odwiedzających Tatrzański Park Narodowy. Wczoraj, dziś i jutro turystyki aktywnej i specjalistycznej. Wydawnictwo PTTK „Kraj”, s. 347-358.

Regulamin Straży Ratunkowej Tatrzańskiego Ochotniczego Pogotowia Ratunkowego $z$ dnia 21 lutego $2019 \mathrm{r}$.

Sambotin D., Sambotin A., Patrascoiu M., Coroian A., Merce I.I. (2011). Ecotourism a model of sustainable development of tourism means. Lucrări Ştiințifice, seria 1 , 13(4).

Skawiński P. (2010). Zarządzanie ruchem turystycznym w Tatrzańskim Parku Narodowym. Folia Turistica, Turystyka i Ekologia, 22: 25-34.

Statut Tatrzańskiego Ochotniczego Pogotowia Ratunkowego z dnia 28 października 2017 r.

Szlubowska A. (red.) (2020). Turystyka w województwie małopolskim w latach 2018 i 2019. Urząd Statystyczny w Krakowie, Kraków.

Tomik R. (2013). Znaczenie turystyki aktywnej i jej rozumienie w kontekście dotychczasowych koncepcji podziałów turystyki. W: R. Tomik (red.), Turystyka aktywna w województwie śląskim - wybrane zagadnienia. T. 1. AWF, Katowice, s. 11-24.

BIP (2016). Tatrzański Park Narodowy. Status prawny (https://bip.malopolska.pl/tpnzakopane,m,107096,status-prawny.html; dostęp: 8.01.2021).

GOV (2020). Wprowadzamy stan epidemii w Polsce (www.gov.pl; dostęp: 8.01.2021).

TOPR (2021) (http://www.topr.pl/; dostęp: 8.01.2021).

TPN (2020). Tatrzański Park Narodowy otwarty dla turystów/TPN zamknięty dla turystów - zagrożenie epidemiczne / Opłaty/Sprzedaż biletów wstępu w roku 2020/Sprzedaż biletów wstępu w roku 2019 (www.tpn.pl; dostęp: 8.01.2021).

\section{The influence of the "defrosting" of the economy after lockdown due to COVID-19 on the volume of tourist traffic in the Tatra National Park}

As a result of the announcement of the global COVID-19 pandemic, a lockdown was established in Poland in March 2020. Apart from preventing or limiting the activity of many branches of the economy, tourist and recreational traffic in parks and forests was also temporarily closed. This was due to the inability to legally enter the Tatra National Park. The aim of this article is to investigate how the temporary exclusion of tourism in the Tatras influenced the intensity of tourist traffic during the "economic defrosting" period and later, based on the analysis of the number of tickets sold, but also the records of the TOPR intervention chronicle in the period from May to September 2019 and in the same period of 2020. 